\title{
Fusion project back on track as US returns to the fold
}

\section{Geoff Brumfiel, Princeton}

The United States is to enter negotiations to rejoin ITER, the international magneticfusion experiment, sharply reviving expectations that the US\$5-billion project will be built.

US energy secretary Spencer Abraham announced the move on 30 January during a visit to the Princeton Plasma Physics Laboratory in New Jersey. The United States will join this year's negotiations to select a site for the project, he said, and is expected to contribute about a tenth of ITER's total costs. The project's current members Japan, Russia, the European Union and Canada - are soon to be joined by China, which announced its intention to participate a few weeks ago (see Nature 421, 306; 2003).

The US contribution to the project would amount to about $\$ 50$ million a year over ten years - less than the annual $\$ 80$ million it spent during the project's design phase.

President Bush confirmed the decision in a statement. "The results of ITER will advance the effort to produce clean, safe, renewable and commercially available fusion energy by the middle of this century," he said.

The US decision to rejoin the project was warmly welcomed by fusion researchers around the world as an important step towards making ITER — formerly known as the International Thermonuclear Experimental Reactor - a reality. "The level of US fusion physics is extremely high, and we are very happy that we'll be working together," says Yoshikazu Okumura, a fusion scientist at the Japan Atomic Energy Research Institute.

ITER was originally conceived as a prototype reactor that would sustain a fusion reaction in a plasma of hydrogen isotopes magnetically contained in a doughnut-shaped device called a tokomak. The United States, Japan and the European Union each spent several hundred million dollars to draw up blueprints for the machine. But concerns over its \$10-billion price tag, questions about its ability to reach design goals, and general budget constraints caused Congress to withdraw funding for the project, cancelling US involvement (see Nature 394, 511; 1998).

The remaining partners pared down the original plans to a less ambitious $\$ 5$-billion design, and the Bush administration expressed an early interest in rejoining the project (see Nature 415, 247-248;2002). The revised design won the support of the US fusion community last summer, and a cost

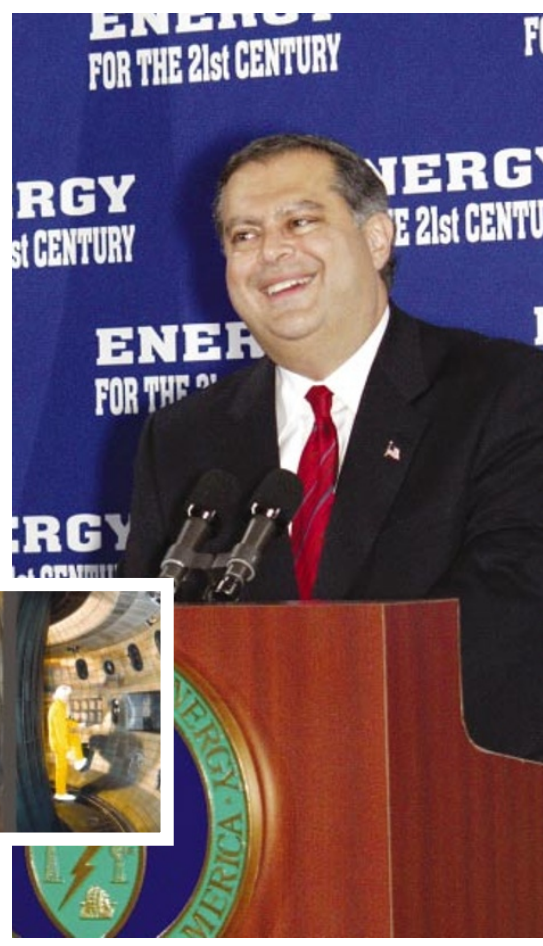

Spencer Abraham reveals US plans to rejoin an international effort to build a tokomak larger than the DIII-D in San Diego (inset).

review by the Department of Energy completed late last year said that its price tag was realistic. "Our estimates and simulations give us confidence that ITER will work," says Raymond Orbach, head of the energy department's Office of Science, who will lead the US team at ITER's next round of negotiations in St Petersburg, Russia, on 18 February.

"I think current partners will be encouraged by US participation," says Robert Aymar, head of the ITER project, who is based in Garching, Germany. But Aymar says that he hopes the United States will consider paying more than $10 \%$ of the project's cost.

The planning process has been slowed in the past by political in-fighting among partner nations. "Hopefully the Americans will give the process a kick forward," says Geoff Cordey, a fusion researcher at the Joint European Torus facility near Oxford, UK.

The next round of negotiations will primarily be concerned with assessing the four proposed sites in Japan, France, Spain and Canada. Murray Stewart, who heads ITER Canada, is confident that, with its new partners, a site will be selected in a timely fashion. "The negotiations are proceeding very quickly," he says, adding that he thinks construction could begin by 2006 .

www.iter.org
Fading support ends Europe's dreams of neutron supremacy

Quirin Schiermeier, Munich

Plans for the European Spallation Source (ESS) - a state-of-the-art facility for neutron science - are near to collapse this week, after Germany and Britain indicated that they would not support its construction.

Germany's research minister Edelgard Bulmahn was expected to tell the country's cabinet this week that investment in the E1.4-billion (US\$1.5billion) facility would put too much strain on Germany's science budget. And last month, says Dieter Richter, scientific director of the ESS project, Britain quietly revoked support for it at a research infrastructure meeting in Brussels.

The ESS, which was first proposed more then ten years ago, was to be the most powerful neutron source in the world. An estimated 5,000 European scientists use neutrons to observe the detailed molecular structure of everything from plastics to proteins.

But a leaked document from a meeting last month of the European Strategy Forum on Research Infrastructures states that "there is not sufficient support from among the Member States" for the realization of the ESS.

As a result of these developments, the ESS project team will be dissolved later this year, says Peter Tindemans, chairman of the ESS Council. "It makes no sense, under the current circumstances, to carry on with technology development," he says.

The decision is a crippling blow for an area of science in which Europe has long excelled. "Even US science advisers admit that Europe has global leadership in neutron research," says Richter. "Without the ESS we will soon lose it to Japan and the United States, which are both building and upgrading powerful neutron facilities."

The last hope for the project is that a scaled-down version might be built with financial support from one of the regions that applied to host the original facility.

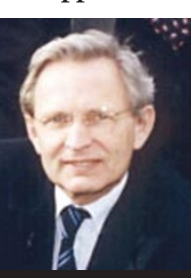

Peter Tindemans: forced to halt neutron project. A former airfield near Selby, UK, and a greenfield site in Sachsen-Anhalt, eastern Germany, had been selected as potential sites, and both regions may continue to push for the construction of a neutron source.

www.ess-europe.de/ ess_js/index.html 